\title{
Oral and maxillofacial trauma in patients with epilepsy Prospective study based on an outpatient population
}

\author{
Eduardo Ruocco Nonato', Moacir Alves Borges ${ }^{2}$
}

\begin{abstract}
Objective: This study aimed to evaluate oral and maxillofacial trauma caused by falls during epileptic seizures. Method: A prospective case-control study was carried out among patients recruited from both the Epileptic Outpatient Clinic and the Emergency Room of Hospital de Base during 2006. The study group was composed of patients with epilepsy that had been diagnosed by a specialist. Oral and maxillofacial trauma was diagnosed using a questionnaire together with physical and radiographic examinations. A control group was formed from non-epileptic relatives or neighbors of the patients. The two groups were compared with regard to the number and type of oral and maxillofacial trauma events suffered. Odds ratios with a $95 \%$ confidence interval, dependency analysis and the Pearson $\chi^{2}$ test were used for statistical analysis, and the significance level was set at $p \leq 0.05$. Results: $A$ total of 159 patients with epilepsy ( 91 males; $57.3 \%)$ and 68 control individuals (28 males; $41.1 \%$ ) were enrolled in the study. The frequencies of oromaxillary trauma in the study and control groups were $23.9 \%$ and $4.4 \%$, respectively. Generalized tonic-clonic, generalized and non-classified seizures were strongly associated with trauma. The commonest lesions were fractures of dental tooth crowns (32.9\%), followed by tooth avulsion (7.6\%), tooth luxation (5\%) and fracturing of prostheses in edentulous patients (3.8\%). Conclusion: This work shows that injuries to the face and teeth are statistically more common in patients with epilepsy than in the general population, and that individuals who suffer seizures without aura are the most affected.
\end{abstract}

Key words: epilepsy, oral trauma, maxillofacial trauma.

\section{Trauma oral e maxilofacial em pessoas com epilepsia: estudo prospectivo com base} ambulatorial

\section{RESUMO}

Objetivo: $\bigcirc$ objetivo desse estudo foi avaliar a relação da epilepsia sobre as ocorrências de trauma dento-alveolar e maxilofacial causados por quedas. Método: Estudo casocontrole prospectivo foi conduzido no ambulatório de epilepsia e do Pronto Atendimento do Hospital de Base de São José do Rio Preto-SP no ano de 2006. Pacientes do grupo caso foram diagnosticados pelo neurologista chefe (sênior) especialista em epilepsia e avaliados quanto ao trauma oral e maxilo-facial pelo pesquisador, por meio de questionário, exame clínico e radiográfico, por ordem de chegada. O grupo controle (GC) foi constituído incluindo indivíduos sem crises, que fossem familiares ou vizinhos próximos dos pacientes com diagnóstico de epilepsia. Intervalo de confiança 95\%, ODD, análise de dependência (ANADEP) e $\chi^{2}$ de Pearson foram utilizados para análise estatística e se adotou nível de significância de $p \leq 0,05$. Resultados: Analisaram-se 159 pacientes com

\section{Correspondence} Eduardo Ruocco Nonato Rua Nair do Santos Lima 110 15090-290 - S.J. do Rio Preto SP - Brasil E-mail eduardornonato@hotmail.com

Received 21 August 2010 Received in final form 4 January 2011 Accepted 14 January 2011 epilepsia, dos quais $91(57,3 \%)$ masculinos e 68 do GC, dos quais $28(41,1 \%)$ masculinos. A frequência do trauma oro-maxilar em paciente com epilepsia foi $23,9 \%$ e no GC foi de 4,4. As crises tônico-clônicas generalizadas, crises generalizadas e as não classificadas estão fortemente co-relacionadas ao trauma. Fraturas das coroas dentais $(32,9 \%)$, seguidas de

${ }^{1} M S c$ Student, Dentist in the School of Medicine of São José do Rio Preto, São José do Rio Preto SP, Brazil; ${ }^{2}$ PhD, Professor in the Neuroscience Department, School of Medicine of São José do Rio Preto, São José do Rio Preto SP, Brazil. 
avulsão dentária (7,6\%), luxação dentária (5\%) e fratura da prótese em pacientes edêntulos $(3,8 \%)$ foram as lesões mais encontradas. Conclusão: $\bigcirc$ trabalho mostra que os ferimentos na face e dentes são frequentes em pacientes com crises epilépticas quando comparados ao GC, sendo as pessoas com crises sem a aura as mais afetadas.

Palavras-chave: epilepsia, trauma oral, trauma maxilofacial/epilepsy, oral trauma, maxillofacial trauma.

Epilepsy is a chronic disorder with unpredictably recurring seizures ${ }^{1}$. Epileptic seizures are the result from temporary dysfunction of the brain caused by diffuse (self-limiting) abnormal hypersynchronic electrical discharges from the cortical neurons ${ }^{2}$.

In the city of São José do Rio Preto, according to a study by Borges et al. ${ }^{3}$, the prevalence of epilepsy is estimated to be 18.6 per 1000 inhabitants and is closely associated with individuals' social class. Using the same methodology in the cities of São José do Rio Preto and Campinas, these authors subsequently confirmed this estimate $^{4}$.

Epileptic seizures are classified as partial or generalized $^{5}$. Partial epileptic seizures are subdivided into simple or complex, with the possibility that both of these can evolve to generalized tonic-clonic seizures. Tonic-clonic seizures are today popularly called convulsions and in the past the manifestations of "falling sickness" caused panic among bystanders and family alike . $^{6}$

The fact that seizures occur without forewarning exposes patients with epilepsy to the risk of injury. Some researchers ${ }^{7-9}$ have reported a correlation between epileptic seizures, in particular generalized atonic seizures and tonic-clonic seizures, and head and facial injuries.

The aim of this study was to evaluate the relationship between epilepsy and the occurrence of dentoalveolar and maxillofacial trauma due to falls.

\section{METHOD}

A case-control study was carried out based on the premise that epileptic seizures may be a determining factor in dentoalveolar and facial injuries due to falls.

This study was approved by the Research Ethics Committee of the School of Medicine of São José do Rio Preto (protocol 016/2005-13/02/2006), and all individuals who agreed to participate in the study were required to give their informed written consent.

The study was performed in the Epilepsy Outpatient Clinic of the Neurology Department of Hospital de Base (FAMERP/FUNFARME) in São José do Rio Preto, Brazil. Hospital de Base is a tertiary-level hospital that treats victims of dentoalveolar and facial injuries.

A total of 159 adult patients with epilepsy who lived in the urban region of São José do Rio Preto were enrolled in the study according to their order of arrival.
Sixty-eight individuals were also recruited for this study to form a control group. An experienced neurologist treated the patients and diagnosed the type of epilepsy. The diagnosis was based on the patients' clinical history and on data gathered from the patients and from individuals accompanying the patients. The patients' medical records and complementary examinations were also analyzed. Data relating to dentoalveolar and maxillofacial trauma during 2006 were gathered with regard to both the epilepsy patients and the control group by a specialist, using a questionnaire that included questions about the frequency and causes of traumas and the management adopted, as well as personal data.

\section{Statistical analysis}

Percentages and descriptive statistics were used to characterize the study participants with regard to gender, age, schooling, type of seizure, frequency of seizures and tooth and facial injuries. Dental trauma, facial injuries and the combination of dental trauma and facial injuries were the independent variables of greatest interest in the analysis. Odds ratios with a 95\% confidence interval were calculated to compare the chances of trauma occurring among the epilepsy patients and in the control group. The degree of association between trauma and epilepsy and the homogeneity test with dependency analysis and the Pearson chi-square test complemented the comparison between the two groups. Data were input on MS Excel 2007 spreadsheets and analyzed using the Minitab 15.1 computer program. The significance level was set at $\mathrm{p} \leq 0.05$.

\section{RESULTS}

Out of the 159 epilepsy patients, 91 (57.3\%) were male and 68 (42.8\%) were female. The patients' mean age was 35.8 years (standard deviation, $\mathrm{SD}=12.8$; range: 14 to 75 years). The mean age for men in this group was 35.6 years (range: 14 to 75 ) and for women, 36.2 years (range: 14 to 64 ). Twenty-eight (41.1\%) of the 68 individuals in the control group were men. The mean age among the controls was 47 years ( $\mathrm{SD}=17.6$; range: 12 to 82 ) with a mean of 51.7 years (range: 12 to 82 ) for men and 44 years (range: 15 to 72 ) for women. Thus, there was a significant difference in mean age between the epilepsy patients and the controls $(\mathrm{p}=0.000)$. Table 1 lists the characteristics of the epilepsy patients' condition. 


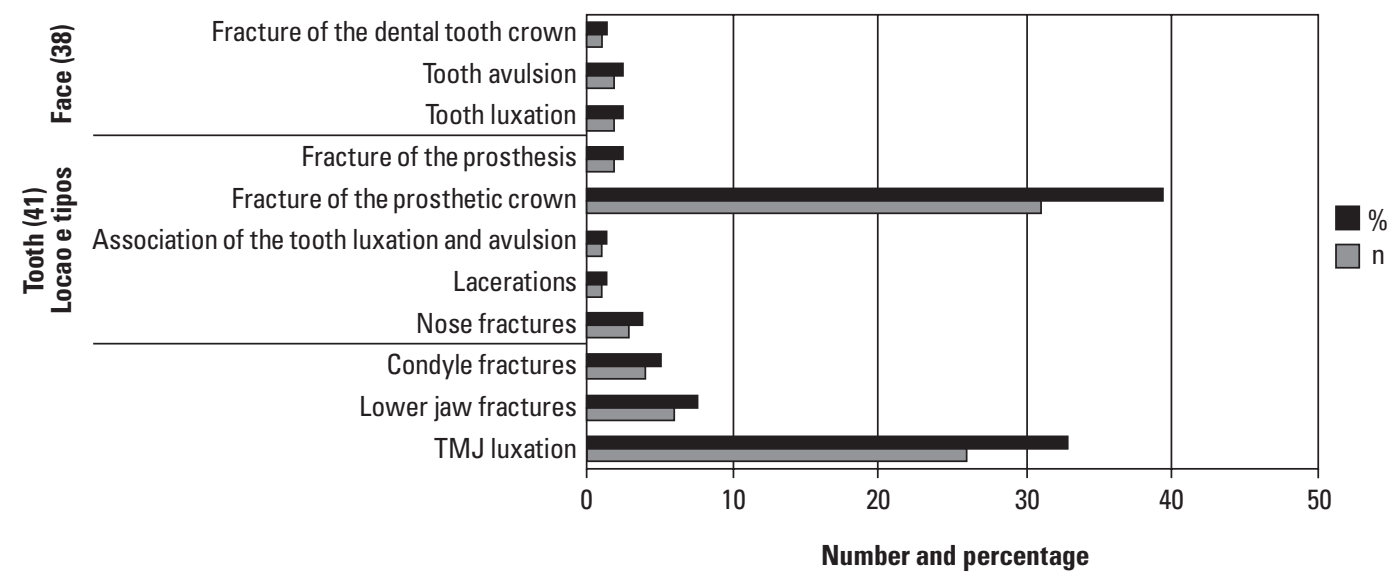

Fig 1. Main types among the 79 orofacial lesions that occurred during epileptic seizures.

Table 1. Clinical characterization of the epilepsy in the study group.

\begin{tabular}{|c|c|}
\hline Variables & $\mathrm{N}=159$ \\
\hline \multicolumn{2}{|l|}{ Type of seizures } \\
\hline Non-convulsive seizure ${ }^{1}$ & 19 \\
\hline CTC without aura ${ }^{2}$ & 57 \\
\hline CTC with aura ${ }^{3}$ & 83 \\
\hline \multicolumn{2}{|l|}{ Frequency of seizures } \\
\hline Without & 33 \\
\hline Annual & 34 \\
\hline Quarterly & 46 \\
\hline Weekly & 46 \\
\hline Age at onset & $17.3 \pm 12.2$ \\
\hline Duration (years) & $18.3 \pm 12.5$ \\
\hline \multicolumn{2}{|c|}{$\begin{array}{l}{ }^{1} \text { Includes non-convulsive generalized seizures, partial seizures (simple } \\
\text { with or without automatisms) without evolution to tonic-clonic seizures } \\
\text { and non-classified seizures; }{ }^{2} \text { Partial seizures (simple with or without } \\
\text { automatisms) with evolution to tonic-clonic seizures (without aura); }{ }^{3 T} \text { Tonic- } \\
\text { clonic seizures with aura (simple and/or with automatisms) with evolution } \\
\text { to tonic-clonic seizures. }\end{array}$} \\
\hline
\end{tabular}

The frequencies of trauma to the face and teeth were compared between the epilepsy patients and the controls (Table 2). The epilepsy patients were found to have suffered significantly more facial and dental injuries $(\mathrm{p}=0.000)$.

Figure 1 shows that the most common oral trauma caused by seizures was fracturing of the dental tooth crown (32.9\%), followed by tooth avulsion (7.6\%), tooth luxation (5\%), fracturing of the prosthesis in edentulous patients $(3.8 \%)$, an association of tooth luxation and avulsion (1.3\%) and fracturing of the prosthetic crown (1.3\%). Lacerations were the most common facial injuries $(29.5 \%)$, followed by nose fractures (2.5\%), condyle fractures $(2.5 \%)$, lower jaw fractures $(2.5 \%)$ and temporomandibular joint luxation (1.3\%).
Table 2. Frequency of orofacial traumas among individuals in the study and control groups.

\begin{tabular}{lccc}
\hline Group & $\begin{array}{c}\text { Without trauma } \\
\text { N (\%) }\end{array}$ & $\begin{array}{c}\text { With trauma } \\
\text { N (\%) }\end{array}$ & $\begin{array}{c}95 \% \text { confidence } \\
\text { interval }\end{array}$ \\
\hline Study & 121 & 38 & $69.1-82.7$ \\
Control & 3 & 65 & $-2.6-9.3$ \\
\hline
\end{tabular}

'Odds ratio $=6.8$.

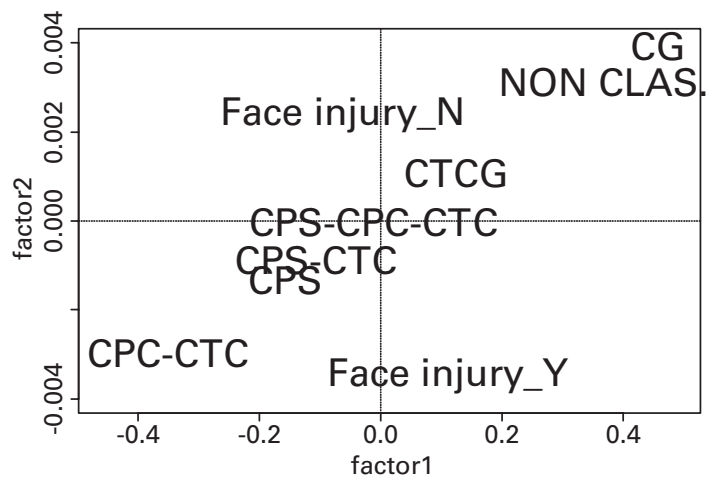

Fig 2. N: without; Y: with; CPC-CTC: complex partial seizure with evolution to tonic-clonic seizures; CPS-CTC: simple partial seizures with evolution to tonic-clonic seizures; CTCG: generalized tonic-clonic seizures; NON CLAS: non-classified; GS: generalized seizures. Dependency analysis and Pearson $/ x^{2}, p$-value $=0.05$.

Figure 2 shows that generalized tonic-clonic, generalized and non-classified seizures were strongly correlated with trauma, while simple and complex partial seizures were associated with non-trauma.

\section{DISCUSSION}

The sample size in this study proved to be satisfactory for reaching reliable conclusions from the statistical analysis. Epilepsy in adults is independent of gender, as also reported by Borges et al. ${ }^{3}$ Most of the study partic- 
ipants were in the adult age range, in which the risk of accidents between the two groups is similar.

The difference between the numbers of men and women in the sample of patients with epilepsy was probably a chance occurrence, whereas the greater number of women in the control group was because the majority of individuals who accompany patients are women. Moreover, among the controls, the mean age of the men was higher than that of the women, perhaps because it is normally older men who accompany patients to consultations.

The results showed that the patients with epilepsy were significantly more susceptible to facial and dental injuries than were the controls. This has been reported by several other authors, including Martin ${ }^{10}$, who stated that medical conditions such as uncontrolled attacks can put patients at risk of suffering orofacial trauma. A study by Aragon et al. found that the injuries caused by falls during seizures, such as lower jaw fractures, mainly related to atonic seizures ("drop attacks") ${ }^{6}$, in which, for example, children hit their chins on a table. This has also been reported in other medical papers. Although atonic seizures are more common during childhood (due to the Lennox-Gastaut syndrome), adults can also suffer generalized atonic seizures ${ }^{11}$ or even negative frontal motor seizures $^{12}$. These types of seizures can cause severe injuries due to falls, especially of the face and mouth, since the head is unprotected ${ }^{13}$. According to Aragon et al., the most common types of injuries that follow seizures are head trauma, fractures, burns and dental trauma ${ }^{8}$. Burns are common particularly in relation to partial seizures with automatisms of the temporal and frontal lobes. Published papers have paid little attention to injuries caused by epileptic seizures, in particular burns, except for a few papers relating to children.

Patients with epilepsy have greater prevalence of injuries to the front teeth because of falls relating to seizures?.

In this work, as also seen by Andreasen et al. ${ }^{14}$, we found that injuries to the dental crown were the commonest type of injuries. These authors reported that the frequency of dental injuries was high in many countries. The most common injuries to the permanent dentition are due to falls, followed by road traffic accidents, physical violence and sport. Traumatic dental injuries represent an acute transmission of energy to the tooth and support structures, which results in fractures, dislocations, crushing of support structures (gums, periodontal ligament and bone), or any combination of these injuries. Silveira ${ }^{15}$ emphasized the high incidence of dental injuries in patients with neurological problems, including epilepsy.

Tooth trauma can be divided into injuries that in- volve the hard tissues of the tooth and pulp (enamel fractures, dentine, dental tooth crown, the root, the alveolar ridge and even the alveolar process) and are classified according to the extent of the injury. Another classification evaluates injury to periodontal tissues, the gums and the cheek mucosa. Injuries to the periodontal tissues can be divided in concussion, subluxation and extrusive luxation lesions ${ }^{14,16}$.

Trauma, especially involving the front teeth, has an unfavorable effect on individuals' functioning, symptomology and physical activities, and it affects their selfesteem, which in turn interferes in behavior and personal success. In childhood, the number of avulsions that occur as a result of trauma is more commonly due to the fragility of the bone tissue that surrounds deciduous teeth. In adults, since the bone structures are more resistant, dental injuries almost always lead to fracturing of the teeth. Bone fractures occurs less frequently and only in more serious accidents ${ }^{17}$.

Some anatomical factors predispose patients and thus increase their susceptibility to dental injuries. These factors include Angle class II malocclusion, overjet exceeding $4 \mathrm{~mm}$, open bite, short and hypotonic lower lip and mouth-breathing ${ }^{18}$. According to Dingman and Natvig $^{19}$, facial fractures can be classified as simple, compound, comminuted and greenstick. With regard to the location of the fracture, they can be classified as in the lower jaw (symphysis region, body, angle, branch, condyle apophysis, coronoid apophysis and alveolar process); zygomatic bone (Group I: without significant dislocation; Group II: fractures of the zygomatic arch; Group III: fractures without rotation of the body; and Group IV: fractures of the body with medial rotation); upper jaw (Le Fort I: horizontal fracture; Le Fort II: pyramidal fracture; and Le Fort III: craniofacial dissociation); and nose bones (inferior and lateral dislocation; separation of the nasal bones at the median line and at the frontal apophysis of the upper jaw; "free open" type fracture; posteroinferior dislocation; comminuted fracture of the nose bones; and fracture of the nasal septum with separation of the nasal bones of the frontal apophysis of the upper jaw).

Fonseca et $\mathrm{al}^{20}{ }^{20}$ reported that $29 \%$ of lower jaw fractures involved the mandibular body; $26 \%$, the mandibular condyle; $25 \%$, the mandibular angle, $17 \%$, the mandibular symphysis, $4 \%$, the mandibular root; and $4 \%$, the mandibular coronoid process.

The causes of $85 \%$ of injuries to the zygomatic bone are robberies, falls and sporting injuries, according to some authors ${ }^{21}$. Fractures of the nasal bones are the most common facial skeletal fractures and account for about $40 \%$ of all facial fractures ${ }^{22}$.

Finally, this study showed that seizures without aura (generalized and partial seizures without aura and with 
evolution to tonic-clonic seizures) are the type of seizures that are most commonly associated with facial and mouth injuries. Individuals who suffer this type of seizure have no time to protect themselves, while patients who suffer seizures with aura (prior warning) are less likely to injure themselves because they are able to prevent falls.

This work shows that facial and dental injuries are more common in patients with epileptic seizures, compared with a control group, and that individuals suffering seizures without aura are the most affected.

\section{REFERENCES}

1. Yacubian EMT. Epilepsias. In: Nitrini R, Bascheschi A (Eds). A neurologia que todo médico deve saber. 2a ed, São Paulo: Ateneu, 2003;11:235-256.

2. Pedley T, Bazil CW, Monell MJ. Epilepsia. In: Rowland LP (Ed). Merritt: tratado de neurologia. 10a ed, Rio de Janeiro: Guanabara Koogan, 2000;140: 705-723.

3. Borges MA, Li M, Guerreiro CAM. Urban prevalence of epilepsy: populacional study in São José do Rio Preto. Arq Neuropsiquiatr 2004;62;199-205.

4. Noronha AL, Borges MA, Marques LH, et al. Prevalence and pattern of epilepsy treatment in different socioeconomic classes in Brazil. Epilepsia 200;748:880-885

5. Commission on Classification and Terminology of the International League against Epilepsy (1981): proposal for revised clinical and electroencephalographic classification of epileptic seizures. Epilepsia 1981;22:489-501.

6. Sanders J, Weddell JA. Managing patients who have seizure disorders: dental and medical issues. JADA 1995;126:1641-1647.

7. Nakken KO, Lossius R. Seizures-related injuries in multihandcapped patients with therapy-resistant epilepsy. Epilepsy 1993;34:836-840.

8. Aragon CE, Burneo JG, Helman J. Occult maxillofacial trauma in epilepsy. J Contemp Dent Pract 2001;2:26-32.

9. Ogumbodede EO, Adamolekum B, Akintomide AO. Oral health and dental treatment needs in nigerians patients with epilepsy. Epilepsia 1998;39: 590-594.

10. Martim BS. Traumatic intrusion of maxillary permanent incisors into the nasal cavity associated with a seizure disorder: reporter of a case. Dental Traumatol 2003;19:286-288.

11. Oguni H, Fukuyama Y, Imaizumi Y, Ueda T. A video-EEG analisis of drop seizure in myoconic astatic epilepsy of early chishood (Doose syndrome). Epilepsia 1992;33:805-813.

12. Geier S, Bancaud J, Talairach J, et al. The seizures of frontal lobe epilepsy: a study of clinical manifestations. Neurology 1977;27:951-958.

13. Tiamkao S, Sawanyawisuth K, Asawavichienjinda T, et al. Predictive risk factors of seizure-related injury in persons with epilepsy. J Neurol Sci 2009; 15;285:59-61.

14. Andreasen JO, Andreasen FM, Bakland LK, Flores MT. Classificação das lesões traumáticas dentais. In: Andreasen JO, Andreasen FM (Eds). Manual do Traumatismo dental. 9a ed. Porto Alegre: Artes Médicas, 2000;3:14-15.

15. Silveira ME. Fratura dentoalveolar. In: Barros JJ, Souza L C M (Eds). Traumatismo buco-maxilo-facial. 2a ed. São Paulo: Roca, 2000;10:265-298.

16. Álvares S, Álvares $\mathrm{G}$. Classificação dos traumatismos dentários: principais danos produzidos. In: Álvares S (Ed). Tratamento do Traumatismo Dentário e Suas Seqüelas. 1a ed. São Paulo: Artes Médicas (EAP-APCD), 1993;3:23-26.

17. Araújo MAM, Valera MC. Etiologia e classificação dos traumatismos dentários. In: Araújo MAM, Valera MC (Eds). $1^{\text {a }}$ ed. São Paulo: Artes Médicas (EAP-APCD), 1999;19:1-12.

18. Mello LL, Muller PR. Lesões traumáticas alvéolo- dentárias : fundamentos. In: Mello LL (Ed). Traumatismo alveolodentário. $2^{\text {a }}$ ed. São Paulo: Artes Médicas (EAP-APCD), 1998;9:1-8.

19. Dingman RO, Nativig P. Princípios gerais. In: Dingman RO (Ed). Cirurgia das fraturas faciais. 1a ed. São Paulo: Santos, 1995:43-96.

20. Barber HD, Woodbury SC, Silverstain KE, Fonseca RJ. Mandubular fractures. In: Fonseca RJ, Walker RV (Eds). Oral and maxillofacial trauma. 2a ed. Philadelphia: Saunders, 1997;17:473-522.

21. Perrott $\mathrm{DH}, \mathrm{Hban}$ LB. Management zigomátic complex fractures. In: Peterson LJ, Indresano AT, Marciani RD, Roser SM (Eds). Oral and maxillofacial surgery. 2a ed. Philadelphia: Linppincott-Raven, 1997;21:489-508.

22. Zide M. Nasal and naso-orbital- ethmoid fractures. In: Peterson LJ, Indresano AT, Marciani RD, Roser SM (Eds). Oral and maxillofaxial surgery. $2^{\text {a }}$ ed. Philadelphia: Linppicott- Raven, 1997;23:547-574. 